\title{
BALTO-SLAVIC ACCENTUAL MOBILITY
}

\author{
FREDERIK KORTLANDT
}

Thomas Olander's dissertation (2006) offers a useful introduction to the history of Balto-Slavic accentuation supported by an impressive command of the scholarly literature. The problem is best discussed against the background of my relative chronology of Balto-Slavic accentual developments (1977: 320-323, 1989: 43-46, cf. Olander 2006: 31f.), which can be summarized as follows:

1. Loss of PIE accentual mobility, of which there is no trace outside the nominal flexion of the consonant stems, e.g. Lith. duktẽ 'daughter', piemuõ 'shepherd', and the flexion of the athematic verbs, e.g. duodãs 'giving' (cf. Kortlandt 1985 on the latter).

2. Pedersen's law: the stress was retracted from medial syllables in mobile accent paradigms, e.g. acc.sg. dùkteri, piemeni, Greek thugatéra, poiména.

3. Barytonesis: the retraction of the stress spread analogically to vocalic stems in the case forms where Pedersen's law applied, e.g. acc.sg. ãvi 'sheep', sūnu 'son', diẽva 'god', žiẽma 'winter'.

4. Oxytonesis: the stress is shifted from a medial syllable to the end of the word in paradigms with end-stressed forms, e.g. inst.sg. sūnumì, inst.pl. žiemomis.

5. Hirt's law: the stress was retracted if the vowel of the pretonic syllable was immediately followed by a laryngeal, e.g. dúona 'bread', výras 'man', dúmai 'smoke', Vedic dhānās, vīrás, dhūmás.

6. Winter's law: the PIE glottalic stops dissolved into a laryngeal and a buccal part. The former merged with the reflex of the PIE laryngeals and the latter with the reflex of the lenes stops, e.g. Latvian pệds 'footstep' < *pedóm, nuôgs 'naked' < *nog ${ }^{w}$ s, duômu 'I give' < ${ }^{\star}$ dod $\mathrm{H}_{3} m i$.

7. Retraction of the stress from final open syllables of disyllabic word forms unless the preceding syllable was closed by an obstruent, e.g. Lith. gen.sg. vilko 'wolf, dat.sg. viîkui, gálvai 'head', nẽša 'carries', Serbo-Croatian vûka, vûku, glâvi, nëse 'carried', neuter pîlo 'drank', but Lith. gen.sg. aviẽs, gen.pl. vilkũ < ${ }^{\star}$-òm, nom.sg. galvà $<^{*}$-àH, Russian pilá 'she drank' ${ }^{*}$-àH, neuter nesló, infinitive nestí, where syllable-final consonants (including word-final laryngeals) prevented the retraction of the stress.

Olander objects to developments 2, 3 and 4 because (unlike 5, 6 and 7) their operation depends not only on phonetic conditions but also on properties of the para- 
digm to which the affected forms belong. The problem was already recognized by Saussure, who stated when he proposed the retraction in dukteri that it is "difficile de dire le caractère exact qu'aurait cette loi, car il y a des obstacles à la transformer en loi phonétique pure et simple" (1896: $163=1922$ : 533). Pedersen observed that “c'est là une loi phonétique d'un type dont les 'néogrammairiens' de la période du renouvellement de la linguistique indo-européenne n'avaient certainement pas rêvé" (1933: 25), and this is why I have called the retraction "Pedersen's law" (1975: 9). Olander's dissertation is a brave attempt at finding a neogrammarian "loi phonétique pure et simple" to account for the rise of the Balto-Slavic mobile accent paradigms. His solution is to adapt the retraction proposed under 7 above in such a way that it covers the barytonesis, to explain the retraction in dukteri by analogy, and to identify the oxytonesis with Saussure's law in Lithuanian and with Dybo's law in Slavic.

A confrontation of Olander's views with mine requires first of all an elucidation of the concept of "unaccented word-forms". Olander uses the term "accent" to refer "to the prominent syllable of a word in prosodic systems where no more than one syllable of a word is prominent relative to its neighbouring syllables" (2006: 10) and mentions Russian, Bulgarian and English as "stress languages" and Vedic, Greek and Japanese as "pitch-accent languages", claiming that "unaccented wordforms" are found in Vedic and Japanese as well as in Proto-Indo-European, ProtoBalto-Slavic and Proto-Slavic. "When pitch, apart from contributing to marking the prominent syllable of a word, has a distinctive function", Olander uses the term "tone" (2006: 11), adducing Štokavian, Čakavian, Lithuanian and Greek as examples. He states that "languages like Vedic and Japanese may also be said to have distinctive tone" but that "we may account economically for prosodic systems of this type also in terms of accent" (ibidem). This is a confused report of the facts. In Tokyo Japanese, hasi 'edge' and hasi 'bridge' are homophonous, both having a lowhigh tone contour. The difference between the two is that a following particle has high tone after 'edge' but low tone after 'bridge'. If we define accent in this language as the last of a series of high tones (as is customary), the word for 'edge' is unstressed before a stressed particle but stressed if no particle follows whereas the word for 'bridge' is always stressed on the second syllable and the word hasi 'chopsticks', which has a high-low tone contour, is always stressed on the first syllable. In Vedic Sanskrit, on the other hand, monosyllables could have either high or low tone while polysyllabic word forms lost their only high tone under certain syntactic conditions, giving rise to sequences of up to ten or more syllables with low tones only (cf. Kortlandt 1986: 156). Unlike Tokyo Japanese, Vedic Sanskrit was a restricted tone language, comparable to Serbo-Croatian. While Proto-Japanese had a distinctive opposition between high and low tone on every syllable (cf. Kortlandt 1993, de Boer 2005), Proto-Indo-European probably had a free pitch accent which was lost under certain syntactic conditions. This system has left an interesting trace 
in modern Greek, which allows two high tones on a word form in spite of being an accent language, e.g. to avtokínitó mas 'our car'.

Another distinction which can easily cause confusion is the one between "acute" and "circumflex", which Olander defines in a satisfactory way as follows (2006: 12): "Proto-Balto-Slavic final syllables are referred to as acute if glottalised (or similarly marked), and circumflex if not; the same distinction applies to pre-Lithuanian and pre-Latvian syllables in all positions, and to the reflexes of these syllables in Lithuanian and Latvian". This definition should apply to all Proto-Balto-Slavic and Proto-Slavic final and non-final syllables. Unfortunately, Olander equates "acute" with "long" and "circumflex" with "short" in non-final syllables of his reconstructed forms (ibidem), thereby depriving himself of the possibility to give an adequate account of the data. Consider the following words:

(a) SCr. kräva 'cow', Slovak krava, Polish krowa, Czech kráva, Upper Sorbian kruwa < krówa;

(b) SCr. brázda 'furrow', Slovak brázda, Polish bruzda < brózda, Czech brázda, Upper Sorbian brózda;

(c) SCr. bráda 'beard', Slovak brada, Polish broda, Czech brada, Upper Sorbian broda.

It is clear that we have a distinction between acute (a), long (b) and short (c) vowels here, all of which are reflected as $a$ in South Slavic and Czecho-Slovak and as $o$ in Polish and Sorbian. The acute vowels were lengthened in Czech and Upper Sorbian after the rise of the new timbre distinctions while they remained short in Serbo-Croatian, Slovak and Polish (cf. Kortlandt 1975: 31). In a similar way, the acute vowel of Ukrainian moróz 'frost' remained distinct from both the falling tone in acc.sg. hólovu 'head' and the long rising tone in gen.pl. holiv of the same word. It follows that the glottalization of acute syllables was preserved after the Common Slavic rise of the new timbre distinctions, the metathesis of liquids in West Slavic and the pleophony (polnoglasie) in East Slavic.

Ancient Greek was a restricted tone language, comparable to Vedic Sanskrit but with a limited distribution of high tones and without "unaccented word-forms" except monosyllabic clitics. The Greek "circumflex" was either automatic (cf. Bally 1945: 41f.) or the reflex of a disyllabic sequence of two vowels (cf. Kortlandt 1986: 153f.), e.g. oíkoi 'at home' < ${ }^{*}$-oï, titheĩen 'they may put' < ${ }^{*}$-eïen $(t)$ as opposed to oĩkoi 'houses', lúseian 'they may loosen' with nonsyllabic ${ }^{\star} i$, also boũs 'ox' < ${ }^{*} g^{w} e H_{3} u s$ versus Zeús without an intervocalic laryngeal. The accentual mobility in métēer 'mother', acc. mètéra, gen. mètrós was probably an innovation of the central Indo-European languages (Indo-Iranian, Greek, Balto-Slavic, Germanic) on the analogy of the words for 'father' and 'daughter' (cf. Beekes 1985: 133). Hirt's law restored the initial accentuation in Lith. móte, SCr. mäti. Thus, I am in agreement with Olander on the starting-point of our reconstructions: "The prosodic system of 
Proto-Indo-European was similar to that of Vedic" (2006: 72), with the proviso that "unaccented word-forms" were syntactically conditioned variants with low tones only of certain word forms which had a single high pitch elsewhere. I have argued that this system originated from the Indo-Uralic syllable structure (2004). Unlike Olander, I think that accentual mobility was widespread in Proto-IndoEuropean outside the $o$-stems and the thematic present and that it was largely eliminated in the daughter languages (cf. Beekes 1985, passim, and Kortlandt 1997).

In search of "unaccented word-forms" in Balto-Slavic, Olander adduces several arguments which require attention (2006: 91, 105, 110, 114). In Lithuanian mobile accent paradigms, the accent falls on the syllable preceding the enclitic particles $n(a)$ 'into' of the illative and $p(i)$ 'at' of the allative, e.g. galvõn 'head', darbóp 'work', which is reminiscent of Dolobko's law in Slavic (cf. Kortlandt 1975: 39). In fact, the original accentuation of these case forms is identical with that of the accusative and the genitive, respectively, and the more recent accentuation was taken from the locative (inessive) after Saussure's law (cf. Kortlandt 2005a). The final stress in the locative was an East Baltic innovation of the demonstrative pronoun tàs, which originally had fixed stress (2).

In Latvian, the acute is reflected as a broken tone not only in originally unstressed syllables but also in previously barytone forms of accent paradigm (3), where we would expect a stretched tone if these were prosodically identical with accent paradigm (1). In my view, the tonal oppositions in the East Baltic languages originated from the retraction of the stress from a prevocalic ${ }^{*} i$ (cf. Kortlandt 1977: 324-328). This development is wholly analogous to what we find at a more recent date in the Žemaitian dialects of Lithuanian (cf. Aleksandravičius 1957, Grinaveckis 1973: 83-97). Since the new tone movements were incompatible with glottalization, either the tones or the glottalization had to be eliminated in accent paradigms (1) and (3). While glottalization was lost under the stretched tone in paradigms with fixed stress (1), this solution would yield an alternation between stretched tone and glottalization in paradigms with mobile stress (3). The generalization of glottalization and loss of the stretched tone in paradigms with mobile stress is therefore to be expected. Olander asserts that the generalization of glottalization is unexpected in $o$-stems which are rarely or never used in the plural such as Latvian $\hat{a r s}$ 'open air', zuôds 'chin', Lith. óras, žándas. In fact, orã is quite frequent in Lithuanian, which has preserved pluralia tantum rather than singularia tantum in such instances as linaĩ 'flax', lipaĩ 'glue', namaĩ 'dwelling', paiša ĩ 'soot', plauša ĩ 'bast', also mèsà 'meat', Latvian miesa, Prussian mensā and crauyo 'blood', sticklo 'glass', unlike prassan 'millet', which is a borrowing from Slavic proso. The original meaning of Slavic męso, Vedic māmsám is 'piece of meat' rather than simply 'meat'.

In Prussian, the absence of a macron in words of the type deiws 'god', acc.sg. deinan 'day' may suggest that these were unaccented. It seems to me that no conclusions can be drawn from the absence of a macron. The frequency of these lexemes is in fact an argument against such a conclusion because the orthography of 
the Enchiridion is particularly consistent in frequent forms, such as bhe 'and', the 1st pl. ending -mai (101×, no exceptions), -ck- in tickars, tickra, tickran, tickrai, nitickran, entickrikai, tickrōmai, tickrōmien, tickrōmiskan (16×, 1 exception), -innin nasal presents with suffixal stress (25×, no exceptions) versus single $-n$ - in nasal presents with radical stress (30X, 2 exceptions), etc. Olander rejects my Prussian accent shift without informing his readers how he explains the shifted accent in semmē, weddē, twaīa, twaiāsmu, swaiāsmu, tennā, tennēismu, tennēison, tennēimans, gennāmans, widdewū, widdewūmans, prakāisnan, dessimts, and perhaps in podingan, pogālbenikan, pogāunai, which have a metatonical circumflex (cf. Kortlandt 1974: 302-304), or how he accounts for the difference between po- and $p a$ - or between no and na (cf. Kortlandt 1988: 9of.). Moreover, he does not explain the presence of a macron in the "unaccented word-forms" mèrgan, äntran, àusins, lāiku, lāikumai, kìrdimai, cf. mergūmans, antrā, laikūt, kirdìt.

In Slavic, "unaccented word-forms" are identified with non-desinentially accented word forms of mobile paradigms, which lost the stress to proclitics, prefixes and enclitics, e.g. Russian zá gorod 'out of town', pródal 'sold', SCr. zimūus 'this winter', and changed an acute into a circumflex root syllable (Meillet's law), e.g. SCr. acc.sg. glâvu, sin, Lith. gálva, súnu (3). Olander agrees with my view that the phonetic realization of the "unaccented word-forms" was different from that of "initially accented word-forms" (2006: 112), which implies the existence of a tonal opposition (high versus low?) on initial syllables, as in Vedic and Serbo-Croatian (but not in Tokyo Japanese). Unlike Olander, I think that there was no historical continuity between the Proto-Indo-European prosodic system reflected in Vedic, where the "unaccented word-forms" were syntactically conditioned variants of highpitched word forms, and the Proto-Slavic system, which was largely identical with that of modern Serbo-Croatian. Apart from the fact that there is no evidence for "unaccented word-forms" in Baltic (see above), it is difficult to see how accentual mobility could spread in the masc. o-stems, e.g. SCr. zûb 'tooth', Lith. žañbas, Gr. gómphos, unless the root-accented forms of accent paradigms (2) and (4) were prosodically identical (cf. Olander 2006: 125f.). Note that in Olander's alleged counter-example Lith. brangùs (3) 'dear' for original brángus (1), the accentuation remained unchanged in acc.sg. brángų, brángia, inst.sg. brángiu, brángia, dat.sg. brángiai, nom.pl. brángūs, brángios, acc.pl. brángius, brángias, nom.acc.du. brángiu, brángi, which together are probably more frequent than the case forms where the accentuation was actually changed. Thus, we are left with the question: when did the "unaccented word-forms" lose their high-pitched variants? Even if one sticks to Olander's framework, the question remains: when did the "unaccented word-forms" lose their syntactic conditioning?

Olander interprets the Slavic change of acute into circumflex root syllables in mobile accent paradigms (Meillet's law) "as a neutralisation of this opposition in unaccented syllables, i.e. as a phonetic change, not an analogical development" (2006: 114). This cannot be correct because the prosodic merger of acute and cir- 
cumflex in Slavic was limited to pretonic and post-posttonic syllables. Under the stress and in the first posttonic syllable, the distinctive opposition between acute (glottalized) and non-acute syllables was preserved until the loss of glottalization yielded short vowels with the timbre of the earlier long vowels (cf. Kortlandt 1975 and 1989, passim, Vermeer 1992: 125-130). Unfortunately, Olander does not distinguish between acute and circumflex in non-final syllables and is therefore unable to give an adequate account of the data. As in the case of Latvian, he adduces Slavic ${ }^{\star}$ smôrdz 'stench' and ‘tûkz 'fat' as alleged singularia tantum against the possibility of an analogical circumflex in mobile accent paradigms. Apart from the fact that I reconstruct nom.sg. ${ }^{*}-\dot{o} s$ and inst.sg. ${ }^{*}-\dot{o} H$, as in Russian včerá 'yesterday', for the mobile $o$-stems, his argument is invalidated by Lith. taukaĩ. I shall not discuss Olander's interpretation of Stang's law (ibidem), which is entirely wrong (cf. Kortlandt 2006).

Olander's biggest mistake is the assumption that there was no distinction between acute (glottalized) and non-acute non-final syllables in Balto-Slavic, in spite of his assertion that "Proto-Balto-Slavic non-final long syllables group with final long syllables containing tautosyllabic PIE ${ }^{\star} V h$ in attracting the accent by Saussure's Law in pre-Lithuanian" (2006: 126), in opposition to final syllables not containing tautosyllabic sequences of vowel plus laryngeal. Following his teacher Rasmussen, Olander thinks that the syllabic nuclei of the sequences ${ }^{\star} \bar{V},{ }^{\star} V H,{ }^{\star} V R H$ and ${ }^{\star} V D$ merged after Hirt's law, "yielding a Proto-Balto-Slavic acute (i.e. long) vowel" (2006: 100). However, like his predecessors (cf. Kortlandt 2005c), Olander does not come up with a single example of an acute lengthened grade vowel. Note that original lengthened grade vowels are reflected as non-acute vowels in Latvian âbuõls 'apple', not broken -uô-, SCr. žërāv and Czech žeráv 'crane', not short -av, Lith. gèlà (4) 'pain', žolé (4) 'grass', mèsà (4) 'meat', bére 'strewed', lếke 'flew', srébe 'sipped', SCr. 1st sg. dònijeh 'brought', ùmrijeh 'died', zàklēh 'swore' with a nonacute long root vowel and without mobile stress, thus reflecting the lengthened grade root vowel and fixed radical stress of the Proto-Indo-European sigmatic aorist, and the etyma which I have listed elsewhere (1975: 73-75). It is not true that the accentuation of the sigmatic aorist can be derived from that of the infinitive (thus Olander 2006: 120), as is clear from donijeh beside nèsti, which gave rise to a new infinitive donijeti, similarly (Dubrovnik) rïjet beside réci 'to say', rather than the other way round, cf. also prësti 'to spin', sjëći 'to cut', ३rd sg. aorist prêde, sijječe.

As a result of his disregard of non-acute long vowels in Balto-Slavic, Olander gives a mistaken account of Dybo's law, "according to which the accent was advanced from an accented short syllable to a following syllable" (2006: 115), so that "we do not expect the accent to be advanced from a long vowel" (2006: 120). In fact, Dybo already showed 38 years ago (1968) that the accent was advanced from any non-acute long or short vowel in any non-final syllable except initial syllables in mobile accent paradigms. The accent did not shift to final jers, as I have shown in detail elsewhere (1975: 13-19). "Somewhat surprisingly, the question of the pro- 
sodic properties of the syllable which receives the accent by Dybo's Law is often left unmentioned", according to Olander (2006: 124). It is all the more surprising that he does not mention my treatment of the problem (1975: 32f., 1989: 53f.).

Now we come to Olander's solution for the rise of Balto-Slavic accentual mobility: "a change of a high tone to a low tone in final short or hiatal syllables" (2006: 133), where the hiatus may or may not have originated from the loss of an intervocalic laryngeal. This is a peculiar development. While the shift of a high tone to the left or to the right is a common phonological change and the loss of a high tone under certain syntactic conditions is attested in Vedic Sanskrit and other languages (including Tokyo Japanese), I do not know any example of phonological loss of a high tone on the basis of its position in a word form. Moreover, this solution does not work, as a comparison with the developments cited under 2, 3, 4 and 7 above shows. First of all, the oxytonesis must have preceded Hirt's law because accentual mobility was preserved in Slavic ${ }^{\star} k l e ̌ t b ~ ' s t o r e-r o o m ',{ }^{\star} k y j b$ 'stick', ${ }^{\star}$ synz 'son', *darı 'gift', ${ }^{\star} \operatorname{stan}$ ' 'stand', cf. Lith. klëtis, kú jis, sūnùs, all of which would have received root stress (1) if the accent had been fixed on the second syllable before Hirt's law. It follows that the oxytonesis cannot be attributed to Saussure's law in Lithuanian and to Dybo's law in Slavic. Besides, the accentuation of most case forms remains unexplained (cf. Olander 2006: 136-160):

Nom.sg. Olander correctly predicts Lith. lángas 'window', neuter šálta 'cold', galvà 'head', fem. saldi 'sweet' duktẽe, piemuõ, but not žverris 'beast', lietùs 'rain', arklỹs 'horse', piktàsis 'the angry', where he has to assume analogical developments. It rather appears that the retraction of the accent was prevented by the final ${ }^{*}-s$ here.

Acc.sg. Olander correctly predicts lángą, žvérí, líetų, but not gálvą < ${ }^{\star}$-ām (cf. Kortlandt 2005b: 153f.), dùkteri, píemeni.

Gen.sg. Olander assumes an original hiatus in lángo $<^{*}-\bar{a}$, but not in galvõs, in spite of the circumflex in both Greek and Lithuanian pointing to ${ }^{\star}-a H a s$, and has to assume analogical developments for žveriẽs, lietaũs, dukter̃s, piemeñs, also Russian desjatí 'ten', etc. It rather appears that the retraction of the accent was prevented by the final ${ }^{*}$ s here.

Dat.sg. Olander assumes an original hiatus in lángui $<^{*}{ }^{\star} \bar{o} i$ and gálvai $<^{\star}-\bar{a} i$, early haplology in *-eiei, and analogy for ${ }^{*}$-euei.

Inst.sg. Olander posits both a hiatus and a final laryngeal in lángu $<{ }^{*}$-óeH and gálva $<^{\star}-a ́ \mathrm{HaH}-\mathrm{N}$ in order to account for the combination of retracted stress with an acute ending. This is an arbitrary reconstruction. In my view, the retracted accent points to an earlier ending ${ }^{*}$-oi (cf. Kortlandt 2005b: 154). Olander attributes the final stress in žverimi and lietumi to Saussure's law and in their Slavic counterparts to Dybo's law. The latter cannot be correct because Dybo's law did not shift the accent to final jers (cf. Kortlandt 1975: 15). 
Loc.sg. Olander assumes regular loss of a high tone in ${ }^{*}$-oi but not in ${ }^{\star}-\bar{e} i$ and ${ }^{\star}-\bar{e} u$ and analogical elimination of the laryngeal in ${ }^{\star}-\bar{a} i$ for ${ }^{\star}-a H i$. This seems quite arbitrary to me.

Nom.acc.du. Olander has to assume analogical developments for lángu, žvëri, súnu and Slavic *sötě 'hundred' and posits both a hiatus and a final laryngeal in gálvi < ${ }^{*}$-áHiH in order to account for the combination of retracted stress with an acute ending. I reconstruct a dual ending ${ }^{*}-H_{1}$ for animates and ${ }^{\star}-i$ for inanimates (1991: 5f.), which yields a retraction from ${ }^{*}$-oi in the inanimate $o$-stems and an acute ending for the animates.

Nom.pl. Olander's rules correctly predict gálvos and Slavic ${ }^{\star}$ søtà but yield the wrong output for langaĩ, geríeji 'the good', žvërys, sünūs, dùkteres, all of which therefore require analogical explanations.

Acc.pl. Olander assumes regular loss of a high tone in the endings of lángus, gálvas, žvéris, lietus followed by phonetic lengthening of short vowels before ${ }^{*}-n s$, allegedly giving rise to glottalization in the final syllable. In my view, the acute ending spread from words with a stem-final laryngeal which was lost before ${ }^{*}-m$ but not before ${ }^{\star}-n s$, yielding an alternation between acc.sg. ${ }^{\star}-\bar{a} m,{ }^{*}-\bar{i} m,{ }^{\star}-\bar{u} m$ and acc.pl. ${ }^{*}-a H n s$, ${ }^{\star}-i H n s,{ }^{\star}-u H n s$, which was followed by a generalization of the glottalization in the acc.pl. endings (cf. Kortlandt 2005b: 153f.).

Gen.pl. The original gen.pl. ending was ${ }^{\star}$-om, as in Vedic asmấkam, Latin nostrum, Old Norse vár 'of us', identical with the neuter ending of the possessive adjective, and regularly developed into Balto-Slavic ${ }^{\star}-u n$ in all flexion classes, preceded by the zero grade of a formative suffix (cf. Kortlandt 1978). Olander reconstructs an accented full grade suffix in ${ }^{*}$-óom, ${ }^{*}$-áHom, ${ }^{*}$-éiom, ${ }^{*}$-éuom, which forces him to

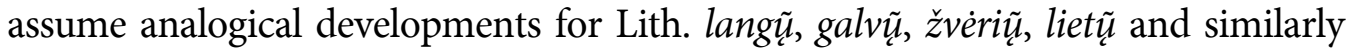
for the Slavic $o$ - and $a H$-stems, attributing the final stress in the Slavic $i$ - and $u$ stems to Dybo's law. The latter cannot be correct because Dybo's law did not shift the accent to final jers (cf. Kortlandt 1975: 15). I would maintain that the retraction of the accent was prevented by the final nasal consonant in these forms.

Dat.pl. Here again, Olander mistakenly attributes the final stress in Slavic to Dybo's law. In the Slavic $i$ - and $u$-stems, the accent was retracted from the endings ${ }^{*}-b m i$, ${ }^{*}$-rmb to the preceding full vowel because the pretonic medial jer had lost its stressability at the time of the retraction, e.g. Russian détjam 'children', ljúdjam 'people', as is also clear from Slovene gen.pl. ọvac 'sheep' < ovbcì and dánas 'today' $<^{*} d b n b s \dot{b}$. While the regular long rising tone was preserved in the latter instances, it was evidently replaced by the falling tone in the dat.pl. form of the $i$ - and $u$-stems on the analogy of the nom.pl. form, as is clear from Slovene kostẹm 'bones', možêm 'men' (the latter of which adopted the accent of the $u$-stems). Note that Stang's law also skipped pretonic medial jers, e.g. SCr. pöčnèm 'I begin', where the thematic 
vowel had received the stress from the radical jer as a result of Dybo's law (cf. Stang 1957: 115). Contrary to Olander's statement (2006: 155), Slavic * róčcka < ${ }^{*}$ rọč̀ ka did not receive the accent on the medial jer as a result of Dybo's law but is an analogical formation (cf. Dybo 1968: 158, 177).

Inst.pl. In order to avoid the wrong output in Lith. langaĩs $<{ }^{*}$-ois, Olander posits a non-hiatal long vowel here, in spite of the Greek circumflex ending -oĩs. I would maintain that the retraction of the accent was prevented by the final ${ }^{*}-s$ of this ending. Olander regards the final accentuation of galvomis as analogical and attributes the final stress in žverimis and lietumis to Saussure's law and in their Slavic counterparts to Dybo's law. He does not discuss the length of the vowel in the Slavic endings ${ }^{\star}-\bar{y}$ and ${ }^{\star}-m \bar{i}$, e.g. Slovene stabrí 'pillars', kostmí 'bones', which is incompatible with the operation of Dybo's law in these forms (cf. Kortlandt 2006). The non-acute stem vowel of Lith. loc.sg. viẽtoje 'place', dat.pl. viẽtoms, inst.pl. viẽtomis, loc.pl. viẽtose was taken from the pronoun (cf. Kortlandt 2005a: 68).

Loc.pl. The accentuation of these forms was apparently the same as that of the dat.pl. forms. Note that the Latvian locative represents the illative, not the inessive (cf. Vanags 1994, Kortlandt 2005a).

I shall not discuss the verbal paradigms here but limit myself to the observation that Olander's theory cannot account for the difference in vowel length between SCr. sjëći 'to cut' and sijèčèm 'I cut' or between Slovak mohol 'could' < *mòglr and niesol 'carried' <*neslb̀. I conclude that he has not succeeded in deriving the accent patterns of Balto-Slavic mobile paradigms from a "loi phonétique pure et simple" acceptable to the neogrammarians. Le problème reste posé.

\section{REFERENCES}

Aleksandravičius, J.

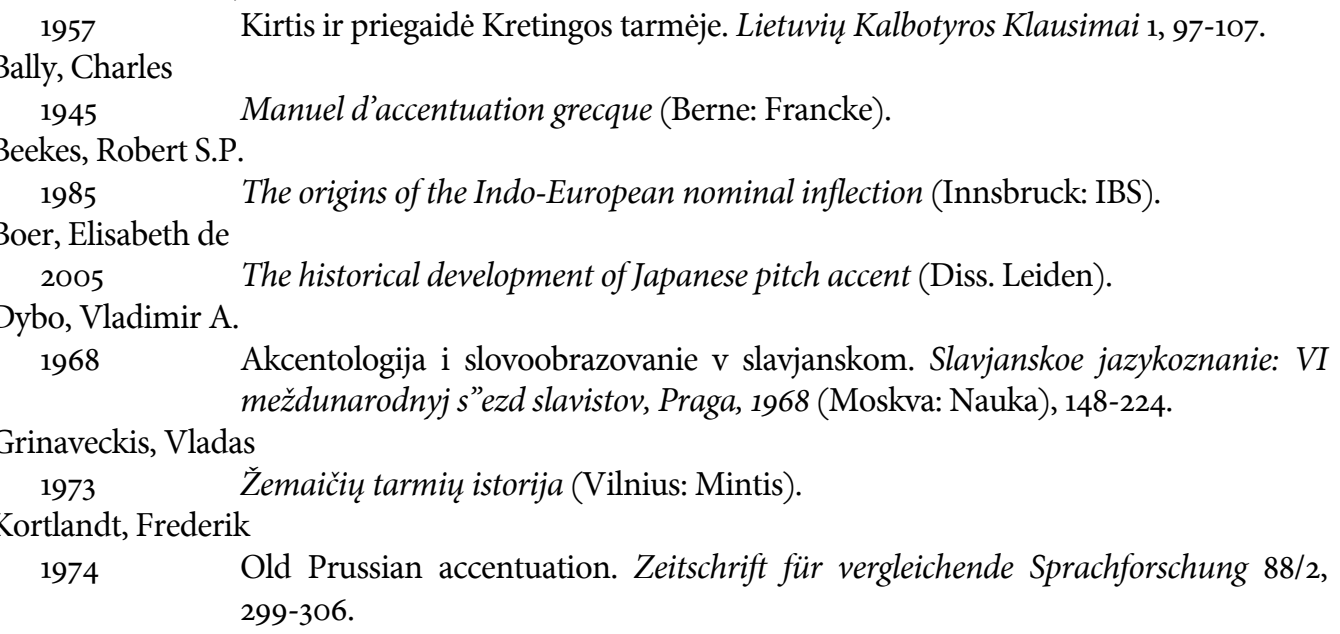


1975

1977

1978

1985

1986

1988

1989

1991

1992

1993

1997

2004

$2005 \mathrm{a}$

$2005 \mathrm{~b}$

$2005 \mathrm{C}$

2006

Olander, Thoma

$$
2006
$$

Pedersen, Holger

1933

Saussure,

Ferdinand de

189

1922

Stang, Christian S.

1957

Vanags, Pēteris

1994

Vermeer, Willem R.

1992 In the beginning was the lengthened grade: On the continuity of Proto-IndoEuropean vowel quantity in Slavic. Rekonstruktion und relative Chronologie: Akten der 8. Fachtagung der Indogermanischen Gesellschaft, Leiden, 1987 (Innsbruck: IBS), $115-136$.

Slavic accentuation: A study in relative chronology (Lisse: Peter de Ridder); also www.kortlandt.nl.

Historical laws of Baltic accentuation. Baltistica 13/2, 319-330.

On the history of the genitive plural in Slavic, Baltic, Germanic, and IndoEuropean. Lingua 45, 281-300.

Slavic imamb. International Journal of Slavic Linguistics and Poetics 31-32, 235-239. Proto-Indo-European tones? Journal of Indo-European Studies 14, 153-16o.

Van Wijk's Altpreussische Studien revisited. Studies in Slavic and General Linguistics 12, 89-97.

Od praindoevropskog jezika do slovenskog (fonološki razvoj). Zbornik za Filologiju i Lingvistiku 32/2, 41-58; English edition: From Proto-Indo-European to Slavic, www.kortlandt.nl.

A note on the Tocharian dual. Tocharian and Indo-European Studies 5, 5-10.

The Aeolic optative. Rekonstruktion und relative Chronologie: Akten der 8. Fachtagung der Indogermanischen Gesellschaft, Leiden, 1987 (Innsbruck: IBS), 235-239. The origin of the Japanese and Korean accent systems. Acta Linguistica Hafniensia 26, 57-65; also www.kortlandt.nl.

Baltic $\bar{e}$ - and $\bar{\imath} / j \bar{a}$-stems. Baltistica $32 / 2,157-163$.

Indo-Uralic consonant gradation. Etymologie, Entlehnungen und Entwicklungen (Helsinki: Société Néophilologique), 163-170.

On the accentuation of the illative. Baltu Filologija 14/1, 67-69.

Holger Pedersen's Études lituaniennes revisited. Baltistica: VI priedas, 151-157.

Noises and nuisances in Balto-Slavic and Indo-European linguistics. Baltistica 40/1, 9-11.

On the relative chronology of Slavic accentual developments. Wiener Slavistisches Jahrbuch 52, 00-00.

Accentual mobility: The prehistory of the Balto-Slavic mobile accent paradigms (Diss. Copenhagen).

Études lituaniennes (København: Levin \& Munksgaard).

Accentuation lituanienne. Indogermanische Forschungen: Anzeiger 6, 157-166.

Recueil des publications scientifiques (Genève: Sonor).

Slavonic accentuation (Oslo: Universitetsforlaget).

Die Entwicklungstendenzen der Kasusendungen in den ältesten lettischen Sprachdenkmälern. Linguistica Baltica 3, 121-130. 